\title{
Akademisyenlerin Uluslararası Kongre Katılım Motivasyonlarının Tespiti
}

\section{Determination of The Academics' Participation Motivation to Internatıonal Congresses}

\author{
Arş. Gör. Özge KOCABULUT \\ Akdeniz Üniversitesi \\ Turizm Fakültesi \\ E-posta: ozgekocabulut@akdeniz.edu.tr
}

Öz

Kongre turizminin geliştirilebilmesi açısından akademisyenlerin uluslararası kongreye katılım motivasyonlarını itici-çekici motivasyon modeli yardımı ile açıklamayı hedefleyen bu çalışmada nitel araştırma yöntemi kullanılmıştır. Araştırma sonucunda, katılımcıların \%90'ı “Akademik eğitime katkı sağlayacak unsurların varlığı"nı önemli bir itici motivasyon faktörü olduğunu" ifade etmiştir. Ayrıca, katılımcıların \%100'ü "Kongrenin akademik olarak yeterli ve başarılı bir ortam sağlamasını" ve "Destinasyona ait turistik ve kültürel çekicilik unsurlarının varlığını" önemli çekici motivasyon faktörleri olarak ifade etmiştir.

Anahtar Kelimeler: Motivasyon, Kongre turizmi, İtici-Çekici Faktörler, Akademisyen

\begin{abstract}
Qualitative research method was used in this study which aimed to explain the participating motivations of academics to international conferences with the help of the push-pull motivation model in terms of the development of congress tourism. For this purpose, to determine the international convention motivations of academics. As a result, research, $90 \%$ of respondents stated "The presence of the elements that contribute to academic education" as an important push motivation. In addition, $100 \%$ of the participants stated that "to provide adequate and successful academic environment" and "the presence of the touristic and cultural attractions of destination" are important pull factors.
\end{abstract}

Keywords: Motivation, Congress tourism, Push-Pull Factor, Academician 


\section{Giriş}

Gelişmiş ve gelişmekte olan ülkeler, turizm faaliyetlerine önem vermekle beraber birtakım sorunlar ile karşılaşmaktadır. Karşılaşılan problemlerin giderilmesindeki çözümlerden biri alternatif turizm faaliyetlerinden yararlanarak turizmin çeşitlendirilmesidir. Çünkü alternatif turizm faaliyetlerinden yararlanan ülkeler, turizm pazarından daha fazla yararlanmış olacak ve alternatif turizm faaliyeti olarak değerlendirilen kongre organizasyonları da ülkeler açısından gelecek vaat eden imkânlar sağlayacaktır.

Kongrelere katılım, akademisyenler tarafından sadece bilimsel veya iş yönlü bir eylem olarak düşünülmemekte aynı zamanda bir seyahat eylemi olarak da değerlendirilmektedir. Ayrıca, akademik çevrede sunulan burs, destek imkânlarının ve kişisel gelişime verilen önemin artması akademisyenlerin uluslararası kongrelere katılım motivasyonlarının da artmasına neden olmaktadır. Ayrıca kongre turizmi, seçilen destinasyon açısından yeni istihdam olanakları yaratmakta ve turizmin 12 aya yayılmasına da imkan sağlamaktadır. Bu bağlamda akademisyenlerin kongre katılım motivasyonlarının tespiti önem arz etmektedir. Bu çalışmanın amacı akademisyenlerin uluslararası kongreye katıım motivasyonlarını itici-çekici motivasyon modeli yardımı ile keşfetmektir. Akademisyenlerin uluslararası kongre katılım motivasyonlarının tespit edilmesi destinasyon yetkililerinin ve işletmelerinin bu kitlenin önem verdiği motivasyon unsurlarını tatmin edecek ürünler sunabilmeleri açısından önem arz etmektedir.

\section{Motivasyon}

İnsan davranışlarının gücü ve yönüyle ilişkili bir kavram olan motivasyon, Latince'de hareket anlamına gelen "movere" kelimesinden türemiştir (Dörnyei ve Ushioda, 2011). Motivasyon bir yoksunluk veya intiyacı gidermek için gerekli davranışları başlatan bir çeşit kuvvettir (Kim, 1996). Bu kuvvet, bireyi iç veya dış uyaranların etkisiyle harekete hazır hale getirerek, bir takım davranışlarda bulunmasını ve bu davranışları devam ettirmesini sağlamaktadır. Kısacası motivasyon, davranışı harekete geçiren iç faktörleri ve bireyi davranışa teşvik eden dış faktörleri ifade etmektedir (Waterman, 2005).

Turizm literatüründe motivasyon, neden turistlerin belli yönlerde ve şekillerde davranışlar sergilediğini anlamak için bir kuvvet ve seyahat davranışını tetikleyici işlevlere sahip bir kavram olarak kabul edilmektedir (Meng, Tepanon ve Uysal, 2006; Devesa, Laguna ve Palacios, 2010). Bu nedenle, kişilerin neden seyahat ettiklerini, nereye seyahat edeceklerini ve nasıl karar verdiklerini anlamak maksadıyla motivasyon ile ilgili birçok çalışma yapıldığı görülmektedir (Devesa, Laguna ve Palacios, 2010). Turizm literatüründeki ana araştırma konularından biri olarak kabul edilen motivasyon teorilerinin temelini, Abraham Maslow'un (1943) "İhtiyaçlar Hiyerarşisi” oluşturmaktadır. Maslow, her bireyde hiyerarşik olarak beş temel ihtiyaç türü olduğunu ileri sürmüştür. İlgili intiyaç türleri sırasıyla şu şekildedir: Fizyolojik intiyaçlar, güvenlik intiyacı, sevgi ve aidiyet intiyacı, saygı intiyacı ve kendini gerçekleştirme (Maslow, 1970; Koçel, 2005; Hsu ve Huang, 2008; Robbins ve Judge, 2013; Wu ve Pearce, 2014).

Pearce (1988) Maslow'un "İhtiyaçlar Hiyerarşisi”ni turizm alanına uyarlayarak, seyahat motivasyonunu açıklamada ilk araç olarak kabul edilen "Seyahat Kariyer Basamağı Teorisi"ni geliştirmiştir (Pearce ve Lee, 2005; Musai, Mahrera ve Arkadani, 2013) Bu teoriye göre, turist motivasyonu beş farklı seyahat intiyacı basamağından oluşmaktadır (Şekil 1). En alt düzeyde dinlenme intiyacı bulunmaktadır. Bunu uyarılma ihtiyacı, insan ilişkisi ihtiyacı, özsaygı ve gelişim intiyacı ve en üst basamakta yer alan kendinde var olan yetenekleri açığa çıkarma intiyacı takip etmektedir (Pearce ve Lee, 
2005; Musai, Mahrera ve Arkadani, 2013). Pearce (1988)'a göre kişiler birden fazla intiyaca sahip olabildiğinden, farklı basamaklardaki motivasyonlara eş zamanlı olarak sahip olunması mümkündür. Ayrıca kişilerin motivasyonları seyahat deneyimlerine ve yaşam evrelerine bağlı olarak değişiklik gösterebilmektedir (Pearce ve Lee, 2005; Heitmann, 2011).

\section{Şekil 1: Pearce'ın (1988) "Seyahat Kariyer Basamağı” Teorisi}

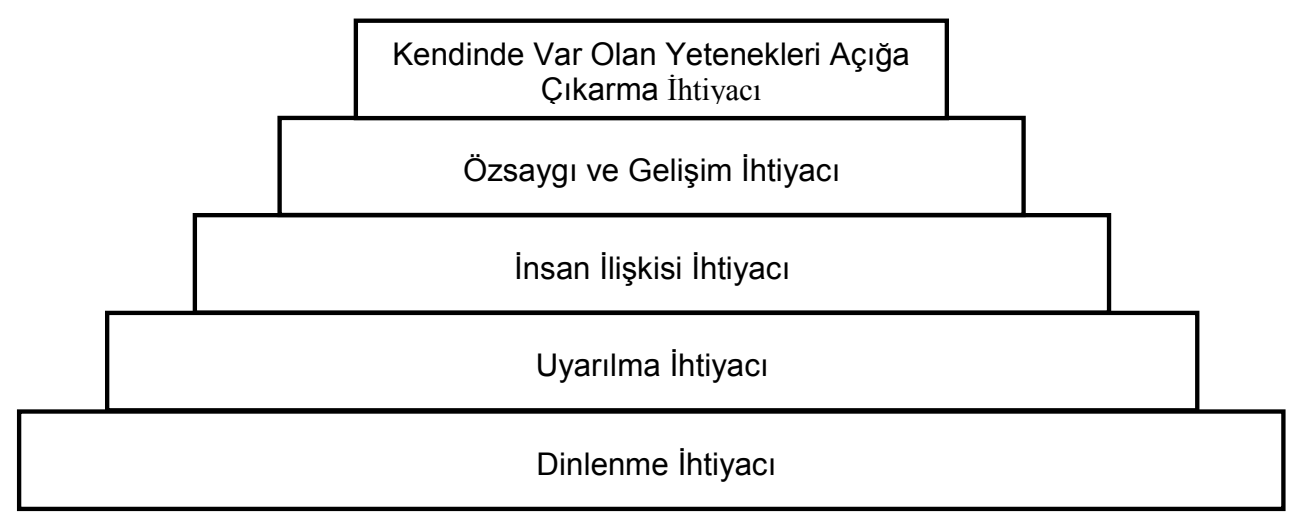

Turizm alanında geniş kabul gören diğer bir teori Iso-Ahola'nın (1982) geliştirmiş olduğu "Optimal Uyarılma (Optimal Arousal) Teorisi"dir. Teori; içsel ödül arayışı (seeking intrinsic rewards) ve rutin çevresel etmenlerden kaçış (escaping routine environments) olmak üzere iki önemli motivasyon faktöründen oluşmaktadır. Iso-Ahola ayrıca bu faktörleri kişisel ve kişilerarası olarak ikiye ayırmıştır (Şekil 2). Kişisel ve içsel ödül arayışı; dinlenme, rahatlama, prestij, rekabet ve diğer kültürleri öğrenmeyi ifade etmektedir. Kişilerarası içsel ödül arayışı ise; sosyal etkileşim, yerel halkla etkileşim, bir gruba üye olmak, bilinen bir yerde yeni arkadaş edinmek ve bilinmeyen bir yerde eski arkadaşlarla etkileşim içinde olmayı tanımlamaktadır. Rutin çevresel etmenlerden kaçışın kişisel boyutu; kişisel problemleri ve başarısızlıkları, kişiler arası boyutu ise; aile, arkadaş ve komşulardan uzaklaşmayı içermektedir (Awaritefe, 2004; Snepenger, King, Marshall ve Uysal, 2006; Hsu ve Huang, 2008).

Şekil 2: Iso-Ahola'nın (1982) “Optimal Uyarılma Teorisi”

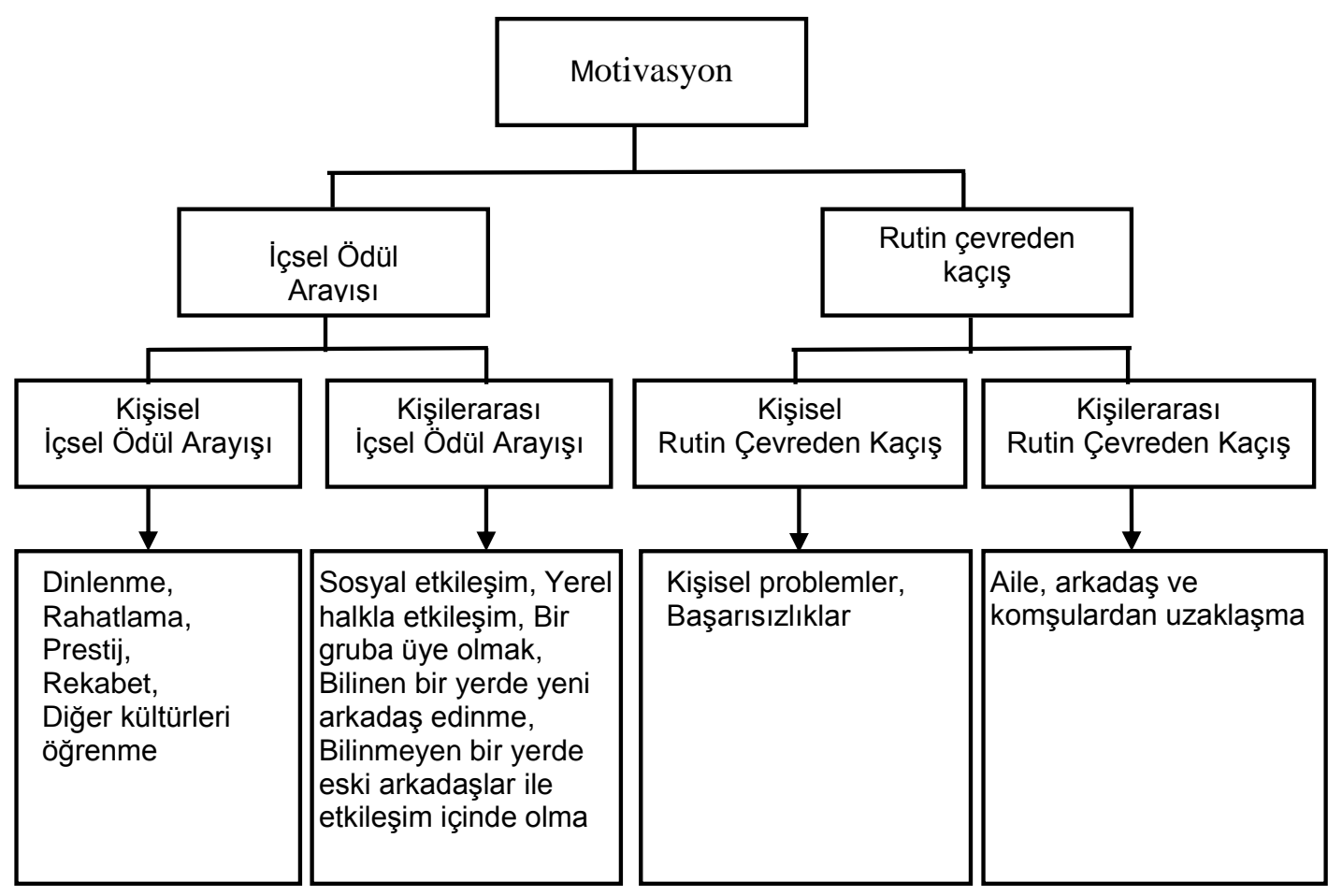


Turistlerin seyahat motivasyonları üzerine yapılmış çalışmaların birçoğunda, "İtici-Çekici Faktörler Teorisi" kullanılmıştır (Oh, Uysal ve Weaver, 1995; Baloğlu ve Uysal, 1996; Mazzarol ve Soutar, 2002). Dann (1981) tarafından geliştirilen teoriye göre, kişiler bazı güçler ya da faktörler tarafından bir davranışa yönelik olarak itilirler veya çekilirler. Kişileri seyahat etmeye iten sebepler itici faktörler olarak adlandırılırken, kişilerin intiyaç ve isteklerine cevap veren destinasyon özellikleri, çekici faktörler olarak adlandırılmaktadır (Baloglu ve McCleary, 1999; Yoon ve Uysal, 2005).

İtici faktörler; kaçış, yenilik, prestij, ilişkileri geliştirme, rahatlama, hobi (Yuan ve Mcdonald, 1990), bulunulan yerden kaçma isteği, kendini keşfetme, rahatlama, prestij, her şeyden uzak kalma isteği, yeni arkadaşlıklar kurma isteği, sosyal bütünleşme (Crompton, 1979) gibi unsurları içermektedir. Bu faktörler, "turistler neden bir yeri diğer bir yere tercih eder veya ne tür deneyimler arayıp, ne tür aktivitelere katılmak ister?" gibi soruları cevaplandırmaya yardımcı olmaktadır (Prayag ve Ryan, 2011).

Çekici faktörler ise kişilerin destinasyon seçiminde önemli etkiye sahip olan (Kim, Lee ve Klenosky, 2003) ve buna bağlı olarak kişisel tercihleri belirleyebilen faktörlerdir (You, O'leary, Morrison ve Hong, 2000). Çekici faktörler; doğal çekicilikler, kültürel ve tarihi kaynaklar, festival gibi eğlence fırsatları, konaklama imkânları, rekreasyonel etmenler gibi unsurları içermektedir (Kim ve Lee, 2002). Bu faktörler turistlerin ne zaman, nereyi ve ne şekilde ziyaret ettikleri hakkında bilgi sunmaktadır (Mill ve Morrison, 1985).

Genel olarak, içsel faktörler bireyleri seyahat etmeye itmekte, destinasyon özelliklerine bağlı dışsal faktörler ise destinasyonlar arası seçim yapmada önemli bir rol oynamaktadır. Ancak çekici faktörler, itici faktörlerin sonucunda etkilerini gösterebilmektedir. Bu bağlamda hem zamansal hem de mantıksal olarak itici faktörler, çekici faktörlerden önce gelmektedir (Dann G., 1977; Girish, 2012). Bu özellikleri ile itici ve çekici faktörlerin birbirlerinden bağımsız bir şekilde değerlendirilmesi mümkün değildir (Baloğlu ve Uysal, 1996; Klenosky, 2002).

\section{Kongre Turizmi}

Etkinlik kavramının bir çeşidini oluşturan kongreler, çeşitli ülkelerden yöneticilerin, delegelerin ve diğer kişilerin katıımı ile gerçekleştirilen; bilgi alışverişinde bulunmak amacıyla düzenlenen toplantılardır. Bu toplantılara katılmak üzere yapılan seyahatler, kongre turizminin konusunu oluşturmaktadır (Montgomery ve Strick, 1995; Çakıcı, 2012). Kongre turizmi "kişilerin uzmanlık gerektiren bilimsel alanlarda veya meslek kollarında, belirli bir konuda bilgi alışverişi yapmak amacıyla bir araya gelmelerinden ortaya çıkan seyahat, konaklama, olay ve ilişkilerin tümü" şeklinde tanımlanmaktadır (Karasu, 1990).

Turizm sektörünün en hızlı büyüyen pazar bölümlerinden biri olan kongre turizminin önemi gün geçtikçe artmaktadır (Karagöz Yüncü ve Kozak, 2010). Özellikle akademik kongreler, kongre turizminin önemli bir bölümünü oluşturmaktadır. Akademisyenlerin uluslararası kongre katılım motivasyonlarının tespit edilmesi destinasyon yetkililerinin ve işletmelerinin bu kitlenin önem verdiği motivasyon unsurlarını tatmin edecek ürünler sunabilmeleri açısından önem arz etmektedir.

Kongre turizminde temel ürün kongrenin kendisi olup, turizm olgusu kongrenin tamamlayıcı bir unsurunu oluşturmaktadır (Karasu, 1990). Bu bağlamda kongre turizmi diğer turizm türlerinden farklı özelliklere sahiptir. Kongre turizmi; sezonu uzatma, yeni iş sahaları yaratarak toplam istihdam kapasitesini artırma, kongre şehrinin altyapı ve 
üstyapı olanaklarını geliştirme, yüksek maliyetli yatırımlar gerektirme gibi özellikler taşımaktadır. Ayrıca toplantı katıımcılarının fiyat hassasiyetinin diğer turistlere oranla düşük olması nedeniyle katılımcıların diğer turistlere oranla daha fazla harcama yapması da kongre turizminin önemli bir özelliğidir. Kongre turizminin bu özelliği, ev sahibi ülke veya destinasyonun elde ettiği turizm gelirlerinin ve dolayısıyla yaratılan ekonomik katkının artmasına yol açmaktadır (Karasu, 1990; Özdemir, 2014).

Kongre turizminin gelişimi açısından, motivasyon faktörleri dışında kişileri kongre turizmine katılmaya sevk eden sebepler de önem arz etmektedir. Kongre katılımcılarının bu organizasyonlara katılım nedenleri ve ilgili destinasyonu tercih etme süreci üzerinde etkisi olan motivasyon unsurları üzerine yapılan çalışmaların sınırlı sayıda olması turizm literatürü açısından bir eksikliktir (Karagöz Yüncü ve Kozak, 2010; Kozak ve Karagöz Yüncü, 2011). Kozak ve Karagöz Yüncü (2010, 2011)'nün çalışmalarında, kongre katılımcılarının başlıca tercihlerinin neler olduğu belirlenmiş; bu maksatla akademisyenlerden elde edilen veri ile tercihler belli kategoriler altında toplanmıştır. Çalışma sonucunda, kongre tercih ölçütlerinin eğlence ve aktivite, kongre, maddi maliyet, altyapı, zaman maliyeti ve destinasyon kategorileri altında toplandığı görülmüştür. Ancak mevcut literatürde akademisyenlerin kongre katılımlarındaki başlıca tercihlerini, itici-çekici faktörler teorisi ile belli kategoriler altında toplamaya çalışan bir çalışmanın bulunmadığı görülmektedir.

\section{Araştırmanın Yöntemi}

$\mathrm{Bu}$ çalışmada akademisyenlerin uluslararası kongre katılım motivasyonlarını tespit etmek maksadıyla nitel araştırma yöntemi kullanılmıştır. Bunun sebebi katılımcıların motivasyonlarını kendi sözcükleriyle ifade etmelerine imkân sağlayarak keşfedici bir araştırma gerçekleştirmektir. Araştırma, Akdeniz Üniversitesi'nde, 38'i Turizm Fakültesi'nin, 22'si İktisadi ve İdari Bilimler Fakültesi İşletme Bölümü'nün bünyesinde yer alan toplam 60 akademisyen ile 2015 yılının Ağustos ayı içerisinde gerçekleştirilmiştir. Kolayda örnekleme yöntemiyle seçilen 60 akademisyene, 6 demografik ve 2 açık uçlu soru yöneltilmiştir. Demografik sorular; cinsiyet, yaş, unvan, fakülte, uluslararası kongre deneyimi ve mesleki deneyim olarak belirlenmiştir. Buna ilaveten, "Uluslararası bir kongreye neden katılmak istersiniz?" ve "Katıldığınız kongrede, kongrenin bulunduğu destinasyon ve tesiste ne gibi özellikler ararsınız?" şeklindeki açık uçlu sorular yardımı ile katılımcıların uluslararası kongre katılımlarına yönelik itici ve çekici motivasyonlarını ifade etmeleri sağlanmıştır. Toplanan verilerin analizi için öncelikle araştırmacılar, bu verilere aşinalık kazanmak maksadıyla birkaç defa okumuştur. Daha sonra ilgili literatürden de destek alınarak araştırmacılar tarafından bir kod şeması oluşturulmuştur. Akabinde toplanan veriler (itici çekici motivasyon ifadeleri) 2 farklı kodlayıcı tarafından kod şeması esas alınarak ilgili kodlara yerleştirilmiştir ve daha sonra araştırmacıların gözetiminde kodlayıcılar bir araya gelerek sonuçları tartışmışlardır. Bu sayede kodlayıcıların aralarındaki farklılıkları gidermeleri sağlanmış ve tek bir kod şemasına ulaşılmıştır.

\section{Bulgular}

\subsection{Katılımcıların Demografik Özelliklerine Yönelik Bulgular}

Katılımcıların \%55'ini (33 kişi) erkekler, \%45'ini ise (27 kişi) kadınlar oluşturmaktadır (Tablo 1). Ayrıca katılımcıların \%50'si (30 kişi) 30 ve daha küçük yaştadır. Diğer katılımcılar ise sırasıyla; \%23,3 (14 kişi) ile 30-40, \%21,7 (13 kişi) ile 41-50 yaş grubunda yer almaktadır. 
Tablo 1: Katılımcıların Cinsiyetlerine, Yaş Gruplarına ve Unvanlarına Göre Dağılımı (N=60)

\begin{tabular}{|c|c|c|}
\hline Demografik Değişkenler & $\bar{f}$ & $\%$ \\
\hline \multicolumn{3}{|l|}{ Cinsiyet } \\
\hline Erkek & 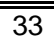 & $\overline{\overline{55,0}}$ \\
\hline Kadın & 27 & 45,0 \\
\hline \multicolumn{3}{|l|}{ Yaş } \\
\hline 30 ve daha küçük & 30 & 50,0 \\
\hline $31-40$ yaş arası & 14 & 23,3 \\
\hline $41-50$ yaş arası & 13 & 21,7 \\
\hline $51-60$ yaş arası & 2 & $\overline{3,3}$ \\
\hline 61 ve daha büyük & 1 & 1,7 \\
\hline \multicolumn{3}{|l|}{ Unvan } \\
\hline Araştırma Görevlisi & 33 & 55,0 \\
\hline Doçent Doktor & 12 & 20,0 \\
\hline Yardımcı Doçent Doktor & 7 & 11,7 \\
\hline Profesör & "5 & 8,3 \\
\hline OÖğretim Görevlisi & 3 & "5,0 \\
\hline \multicolumn{3}{|l|}{ Fakülte } \\
\hline $\begin{array}{l}\text { Turizm Fakültesi } \\
\end{array}$ & 38 & $\overline{663,3}$ \\
\hline İंBF İşletme Bölümü & 22 & 36,7 \\
\hline
\end{tabular}

Katılımcıların büyük bir bölümü \%55 (33 kişi) ile araştırma görevlilerinden oluşmaktadır. Bunu sırasıyla \%20 (12 kişi) ile Doçent doktorlar, \%11,7 (7 kişi) ile Yardımcı Doçent Doktorlar, \%8,3 (5 kişi) ile Profesörler ve \%5 (3 kişi) ile Öğretim Görevlileri takip etmektedir.

Tablo 2: Katılımcıların Mesleki ve Uluslarası Kongre Deneyimi $(\mathrm{N}=60)$

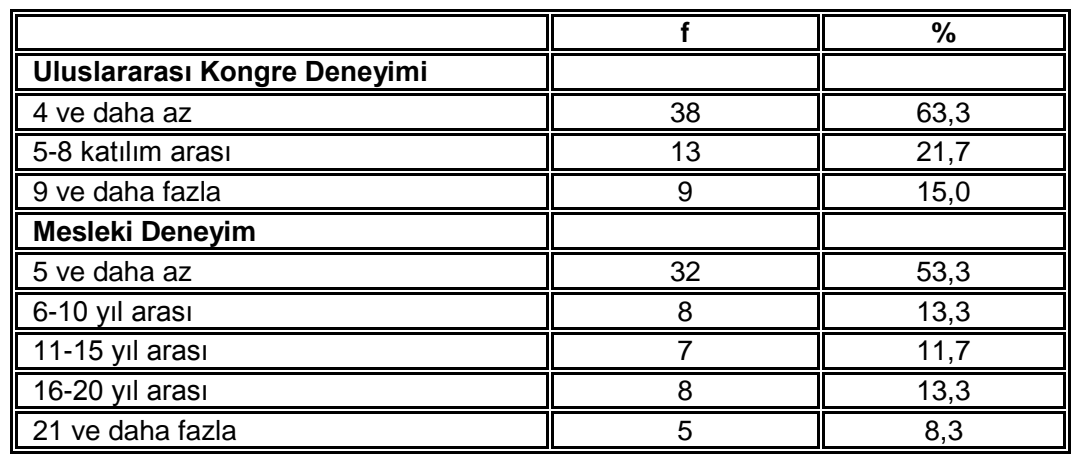

Tablo 2 incelendiğinde, katılımcıların \%63,3 (38 kişi)'ünün 4 ve daha az uluslararası kongre deneyiminin olduğu görülmektedir. Bunu sırasıyla \%21,7 (13 kişi) ile 5-8, \%15 (9 kişi) ile 9 ve daha fazla ululararası kongre deneyimine sahip katılımcılar takip etmektedir. Katılımcıların \%53,3 (32kişi)'nün 5 yıl ve daha az mesleki deneyime sahip olduğu görülmektedir. Bunu sırasıyla \%13,3 (8 kişi) ile 6-10 ve 16-20 yıl arası, \%11,7 (7 kişi) ile 11-15 yıl arası ve \%8,3 (5 kişi) ile 21 ve daha fazla deneyime sahip katılımcılar takip etmektedir.

\subsection{Katılımcıların MotivayonlarınaYönelik Bulgular}


Tablo 3: İtici Faktör Boyutları ve Alt İfadeleri

\begin{tabular}{|c|c|c|}
\hline İtici Faktör Boyutları & $\overline{f f}$ & $\%$ \\
\hline \multicolumn{3}{|l|}{ Arkadaşlar veya aile ile birliktelik sağlama } \\
\hline - - Arkadaşlar ve aile ile birliktelik sağlama fırsatının varlığı & 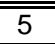 & 8,3 \\
\hline - Meslektaşlar ile buluşma fırsatının varığı & 2 & 3,3 \\
\hline \multicolumn{3}{|l|}{ Rutinden kaçış ve rahatlama } \\
\hline - $\quad$ Farklı bir akademik faaliyette bulunma isteği & 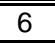 & 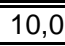 \\
\hline \multicolumn{3}{|l|}{ Yeni arkadaşlıklar kurma } \\
\hline - Alanında uzman ve önde gelen isimlerle bir arada olabilme isteği & 7 & 111,6 \\
\hline - Yeni akademisyenlerle tanışma ve akademik ilişkiler geliştirme isteği & 29 & $\overline{488,3}$ \\
\hline \multicolumn{3}{|l|}{ Yeni yerler görme ve keşfetme } \\
\hline - $\quad$ Farklı destinasyonların kültürünü tanıma ve keşfetme isteği & 41 & 68,3 \\
\hline \multicolumn{3}{|l|}{ Yeni başarılar ve deneyimler edinme } \\
\hline - Akademik tecrübe ve başarı elde etme fırsatının varlığı & 36 & 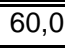 \\
\hline - - Akademik tecrübeleri paylaşma fırsatının varlığı & 14 & 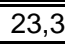 \\
\hline \multicolumn{3}{|l|}{ Eğitim düzeyini ve bilgi dağarcığını geliştirme } \\
\hline - $\quad$ Akademik eğitime katkı sağlayacak unsurların varlığı & "54 & 90,0 \\
\hline \multicolumn{3}{|l|}{ Prestij edinme ve tanınırlık sağlama } \\
\hline - Y Yapılan çalışmalar ile tanınırığı sağlama ve saygınlık kazanma isteği & 3 & $\overline{5,0}$ \\
\hline \multicolumn{3}{|l|}{ Eğlence ve heyecan } \\
\hline - Güzel vakit geçirme fırsatının varlığı & 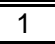 & $\overline{11,6}$ \\
\hline \multicolumn{3}{|l|}{ Üniversitenin veya YÖK'ün sağladığı destekten yararlanma } \\
\hline - Akademik teşviklerden ve ödeneklerden yararlanma fırsatının varlığı & 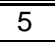 & 8,3 \\
\hline
\end{tabular}

İtici faktörler, daha önceden belirlenen 9 ana başlık altında kodlayıcılar tarafından sınıflandırımıştır. Tablo 3 cevaplayıcıların yüzde kaçının ilgili motivasyonu ifade ettiğini göstermektedir. Katılımcıların \% 90'ı “akademik eğitime katkı sağlayacak unsurların varlığını" önemli bir itici motivasyon faktörü olarak ifade etmiştir. Bunu $\% 68,3$ ile "farklı destinasyonların kültürünü tanıma ve keşfetme isteği" ve \% 48,3 ile "yeni akademisyenlerle tanışma ve akademik ilişkiler geliştirme isteği" takip etmektedir. En az ifade edilen itici motivasyon ise "güzel vakit geçirme fırsatının varlığı" (1 kişi) olarak tespit edilmiştir.

\section{Tablo 4. Çekici Faktör Boyutları ve Alt İfadeleri}

\begin{tabular}{|c|c|c|}
\hline Çekici Faktör Boyutları & 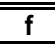 & $\%$ \\
\hline \multicolumn{3}{|l|}{ Maddi maliyete uygunluk } \\
\hline - $\quad$ Konaklama ücretlerinin uygunluğu & 9 & 15,0 \\
\hline - $\quad$ Kongre ücretlerinin uygunluğu & 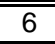 & 10,0 \\
\hline - $\quad$ Yiyecek içecek maliyetlerinin uygunluğu & 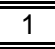 & 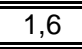 \\
\hline - Kongrenin yapıldığı destinasyonun maddi olarak uygunluğu & 8 & 13,3 \\
\hline \multicolumn{3}{|l|}{ Alt yapı, Teknik ve Fiziki özellikler } \\
\hline - Tesis imajının iyi olması & 3 & 5,0 \\
\hline $\begin{array}{ll} & \text { Tesis hizmet özelliklerinin uygun olması } \\
\end{array}$ & 19 & 31,6 \\
\hline - $\quad$ Kongre merkezinin alt yapısının uygun olması & 28 & 46,6 \\
\hline \multicolumn{3}{|l|}{ Eğlence ve sosyal aktiviteler } \\
\hline - $\quad$ Sosyal ve kültürel etkinliklerin varlığı & 5 & 8,3 \\
\hline \multicolumn{3}{|l|}{ Destinasyonun temel özellikleri } \\
\hline - Destinasyon imajının güçlü olması & 4 & 6,6 \\
\hline - Destinasyona ait turistik ve kültürel çekicilik unsurlarının varlığı & 60 & 100,0 \\
\hline - Destinasyon iklim koşullarının uygun olması & 2 & 3,3 \\
\hline - Destinasyonun güvenilir olması & 12 & 20,0 \\
\hline \multicolumn{3}{|l|}{ Kongrenin temel özellikleri } \\
\hline - $\quad$ Kongre organizasyonunun sorunsuz, güvenilir ve uygun olması & 25 & 41,6 \\
\hline - $\quad$ Kongrenin akademik olarak yeterli ve başarılı bir ortam sağlaması & 60 & 100,0 \\
\hline
\end{tabular}


Çekici faktörler, daha önceden belirlenen 5 ana başlık altında kodlayıcılar tarafından sınıflandırıımıştır. Tablo 4 cevaplayıcıların yüzde kaçının ilgili motivasyonu ifade ettiğini göstermektedir. Katılımcıların \% 100'ü "kongrenin akademik olarak yeterli ve başarılı bir ortam sağlamasını" ve "destinasyona ait turistik ve kültürel çekicilik unsurlarının varlığını" önemli çekici motivasyon faktörleri olarak ifade etmiştir. Bunu \% 46,6 ile "kongre merkezinin alt yapısının uygun olması" ve \% 41,6 ile "Kongre organizasyonunun sorunsuz, güvenilir ve uygun olması" takip etmektedir. En az ifade edilen çekici motivasyon "yiyecek içecek maliyetlerinin uygunluğu" (1 kişi) olarak tespit edilmiştir.

\section{Tartışma}

Antalya destinasyonu deniz-kum-güneş üçlüsünü kullanarak dünya tatil turizmi pazarında belirli bir başarı elde etmiştir. Ancak bu üçlü, sürdürülebilirlik kapsamında, turizmi 12 aya yaymakta yeterli olamamıştır. Bu durum Antalya destinasyonu açısından önemli altyapı ve üstyapı sorunlarına yol açmaktadır. Örneğin azalan talebe bağlı olarak kış aylarında birçok turizm tesisi kapatılmakta ve bu nedenle çok sayıda turizm çalışanı geçici işsizlik sorunu yaşamaktadır. Bu sebeple turizm eğitimi almış olan birçok çalışan farklı iş sahalarında çalışmayı tercih etmektedir. Bu bağlamda turizmin on iki aya yayılması amacıyla, alternatif turizm çeşitlerinden biri olan kongre turizmi Antalya destinasyonu açısından önemli bir fırsat oluşturmaktadır. Kış sezonunda, kongre turizmi faaliyetleri ile turizm faaliyetlerinin canlandırılması mümkün olabilmektedir. Bu sayede yeni istihdam sahaları yaratılması ve destinasyonun toplam gelirlerinin arttırılması da sağlanabilmektedir.

Ancak kongre turizminin bir destinasyonda geliştirilebilmesi için öncelikle katılımcıların başlıca motivasyon unsurlarının tespit edilmesi gereklidir. Bu şekilde katılımcı istek ve ihtiyaçlarını karşılayacak hizmetlerin sunulması mümkün olabilecektir. Bu çalışma, bir kongrenin katılımcılar açısından cazip olabilmesi için hangi özelliklere sahip olması gerektiğini tespit etmeye imkan sağlamaktadır. Araştırmada öne çıkan itici motivasyon faktörü "akademik eğitime katkı sağlayacak unsurların varlığı" olarak tespit edilmiştir. Araştırmada öne çıkan çekici motivasyon faktörleri ise "kongrenin akademik olarak yeterli ve başarılı bir ortam sağlaması" ve "destinasyona ait turistik ve kültürel çekicilik unsurlarının varlığı" olarak tespit edilmiştir. Bu bağlamda akademisyenlerin, kongre organizasyonlarını, sadece bilimsel veya iş yönlü bir eylem olarak düşünmediği aynı zamanda bir seyahat eylemi olarak da değerlendirdiği sonucuna ulaşılmaktadır. Ayrıca ileride yapılacak olan çalışmalarda, keşfedilen tüm bu motivasyon ifadeleri ölçek haline getirilerek kullanılabilir.

Son olarak da çalışmanın kısıtları hakkında şunları söylemek mümkündür. $\mathrm{Bu}$ çalışmada akademisyenlerin uluslararası kongre katılım motivasyonlarının tespiti için 60 akademisyen ile görüşülmüştür. Bu 60 akademisyen sadece Akdeniz Üniversitesi Turizm Fakültesi'nden ve İktisadi ve İdari Bilimler Fakültesi İşletme Bölümü'nden kolayda örnekleme yöntemiyle seçilmiştir. Bu bağlamda bundan sonraki çalışmalarda, farklı üniversitelerin bünyesinde yer alan daha fazla sayıda akademisyen ile çalışma tekrarlanabilir. Ayrıca ileriki çalışmalarda ulusal-uluslararası kongre katılım kıyaslaması yapılabileceği gibi Türkiye'de düzenlenen uluslararası kongrelere yabancı akademisyenlerin katılım motivasyonları da tespit edilebilir.

\section{Kaynakça}

Awaritefe, O. (2004). Motivation and Other Considerationsin Tourist Destination Choice: A Case Study of Nigeria. Tourism Geographies, 6(3): 303-330. 
Baloglu, S. ve McCleary, K. W. (1999). A Model of Destination Image Formation. Annals of Tourism Research, 26(4): 868-897.

Baloğlu, S. ve Uysal, M. (1996). Market Segments of Push and Pull Motivations: A Canonical Correlation Approach. International Journal of Contemporary Hospitality Management, 8(3): 32-38.

Breiter, D. ve Milman, A. (2006). Attendees' Needs and Service Priorities in a Large Convention Center: Application of the Importance-performance Theory. Tourism Management, 27(6): 1364-1370.

Bright, A. D. (2008). Motivations, Attitudes and Beliefs. H. Oh ve A. Pizam içinde, Handbook of Hospitality Marketing Management, Chapter 9: (s. 239-265). Oxford: Elsevier.

Crompton, J. L. (1979). Motivations of Pleasure Vacations. Annals of Tourism Research, 6(4): 408-424.

Çakıcı, C. (2012). Toplantı Yönetimi: Kongre, Konferans, Seminer ve Fuar Organizasyonları. Ankara: Detay Yayınları.

Dann, G. (1977). Anomie, Ego-enhancement and Tourism. Annals of Tourism Research, 4(4): 184-194.

Dann, G. M. (1981). Tourist Motivation: An Appraisal. Annals of Tourism Research, 8(2): 187-219.

Demir, Ş. Ş. (2010). Çekici Faktörlerin Destinasyon Seçimine Etkisi: Dalyan Örneği. Ege Akademik Bakış, 10(3): 1041- 1054.

Demirkıran, E. (2013, Kasım 25). Ocak 21, 2014 tarihinde http://www.erdaldemirkiran.com/tr-1-news-36738-----Motivasyonun_Tanimi\#.VLMbdKsUhM adresinden alınmıştır.

Devesa, M., Laguna, M. ve Palacios, A. (2010). The Role of Motivation in Visitor Satisfaction: Empirical Evidence in Rural Tourism. Tourism Management, 31(4): 547-552.

Dörnyei, Z. ve Ushioda, E. (2011). Teaching and Researching: Motivation. New York: Routledge.

Emir, O. ve Avan, A. (2010). Yabancı Turistlerin Satınalma Karar Sürecinde Kültürel Varlıkların Etkisi: Konya Örneği. Selçuk Üniversitesi Sosyal Bilimler Enstitüsü Dergisi, 24: 203-219.

Evren, S. ve Kozak, N. (2012). Eskişehir'in Çekici Faktörlerinin Günübirlik Ziyaretçilerin Bakış Açısıyla Değerlendirilmesi. Anatolia: Turizm Araştırmaları Dergisi, 23(2): 220-232.

Fenich, G. G. (2001). Towards a Conceptual Framework for Assessing Community Attractiveness for Conventions. Journal of Convention \& Exhibition Management, 3(1): 45-64.

Girish, P. (2012). Senior Travelers' Motivations and Future Behavioral Intentions: The Case of Nice. Journal of Travel \& Tourism Marketing, 29(7): 665-681.

Gnoth, J. (1998). Branding Tourism Destinations. Annals of Tourism Research, 25(3): 758-760.

Heitmann, S. (2011). Peter Robinson. S. Heitmann ve P. Dieke içinde, Research Themes for Tourism : Tourist Behaviour and Tourism Motivation (s. 31-44). Oxford: Cabi International.

Hsu, C. H. ve Huang, S. S. (2008). Tourism Management Analysis, Behaviour and Strategy. A. G. Woodside ve D. Martin içinde, Travel Motivation: A Critical Review of the Concept's Development (s. 14-27). Oxford: Cabi International.

Jang, S. ve Cai, L. A. (2002). Travel Motivations and Destination Choice: A Study of British Outbound Market. Journal of Travel \& Tourism Marketing, 13(3): 111133.

Jang, S. ve Wu, C.-M. E. (2006). Seniors' Travel Motivation and the Influential Factors: An Examination of Taiwanese Seniors. Tourism Management, 27(2): 306-316. 
Karagöz Yüncü, D. ve Kozak, N. (2010). Türk Akademisyenlerin Kongre Tercihleri Üzerine Bir Araştırma. Anatolia: Turizm Araştırmaları Dergisi, 21(1): 109-120.

Karasu, T. (1990). Kongre Turizmi Üzerine Düşünceler. Anatolia Dergisi, 32: 32-34.

Kim. (1996). 1001 Ways to Motivate Yourself and Others. United States of America: Turtle Press.

Kim, E. (1997). Korean Outbound Tourism: Pre-Vi si t Expectations of Australia. Journal of Travel \& Tourism Marketing, 6(1): 11-19.

Kim, S., Lee, C. ve Klenosky, D. (2003). The Influence Of Push And Pull Factors At Korean National Parks. Tourism Management, 24, 169-180.

Kim, S.-S. ve Lee, C.-K. (2002). Push And Pull Relationships. Annals Of Tourism Research, 29(1): 257-260.

Klenosky, D. B. (2002). The "Pull" of Tourism Destinations: A Means-end Investigation. Journal of Travel Research, 40(4): 385-395.

Koçel, T. (2005). İşletme Yöneticiliği. Arıkan Yayınları.

Kozak, M. (2002). Comparative Analysis Of Tourist Motivations By Nationality And Destinations. Tourism Management, 23(3): 221-232.

Kozak, N. ve Karagöz Yüncü, D. (2011). Akademisyenlerin Kongre Tercih Unsurları. Anadolu Üniversitesi Sosyal Bilimler Dergisi, 11(2): 19-32.

MA, F. M. ve Govers, R. (1999). The Asian Perspective: Which International Conference Destinations in Asia Are the Most Competitive? Journal of Convention \& Exhibition Management, 1(4): 37-50.

Mair, J. ve Thompson, K. (2009). The UK association conference attendance decisionmaking process. Tourism Management, 30(3): 400-409.

Maslow, A. (1970). Motivation and Personality. New York: Harper and Row Publisher Inc.

Mazzarol, T. ve Soutar, G. N. (2002). Push-Pull Factors Influencing International Student Destination Choice. The International Journal Of Educational Management, 16(2/3): 82-90.

McGehee, N. G., Loker-Murphy, L. ve Uysal, M. (1996). The Australian International Pleasure Travel Market: Motivations from a Gendered Perspective. The Journal of Tourısm Studies, 7(1): 45-57.

Meng, F., Tepanon, Y. ve Uysal, M. (2006). Measuring Tourist Satisfaction by Attribute and Motivation: The Case of a Nature-based Resort. Journal of Vacation Marketing, 14(1): 41-56.

Mill, R. C. ve Morrison, A. M. (1985). The Tourism System: An Introduction Text. Australia: Englewood Cliffs, N.J. : Prentice-Hall International.

Montgomery, R. J. ve Strick, S. K. (1995). Meetings, Conventions and Expositions. New York: Van Nostand Rainhold and International Thomoson.

Mook, D. G. (1996). Motivation: The Organization of Action (Second Edition). New York: W.W. Norton \& Company.

Murray, E. J. (1964). Motivation and Emotion. Englewood Cliff: NJ: PrenticeHall.

Musai, M., Mahrera, M. ve Arkadani, H. (2013). Motivational Factors of Travel to War Places in Iran. International Journal of Academic Research in Business and Social Sciences, 3(1): 314-323.

Oh, H. C., Uysal, M. ve Weaver, P. A. (1995). Product Bundles and Market Segments

Based on Travel Motivations: A Canonical Correlation Approach. International Journal of Hospitality Management, 14(2): 123-137.

Oppermann, M. (1996). Convention Destination Images: Analysis of Association Meeting Planners' Perceptions. Tourism Management, 17(3): 175-182.

Özdemir, S. S. (2014). Kongre ve Toplantı Otellerinin Rekabet Stratejileri: İzmir Örneği. VII. Lisansüstü Turizm Öğrencileri Araştırma Kongresi, (s. 473-486). Aydın.

Özen, H. (2014). Motivasyonel Dil Teorisi Işığında Okul Müdürlerinin Kullandığı Motivasyonel Dilin Öğretmenlerin Örgütsel Vatandaşlık Davranışlarına Olan 
Etkisi. Turkish Studies - International Periodical For The Languages, Literature and History of Turkish or Turkic, 9(5): 1731-1746.

Pearce, P. L. (1982). The Social Psychology of Tourist Behavior. Ingiltere: Oxford Pergamon.

Pearce, P. ve Lee, U. (2005). Developing the Travel Career Approach to Tourist Motivation. Journal of Travel Research, 43(3): 226-237.

Prayag, G. ve Ryan, C. (2011). The Relationship between the 'Push' and 'Pull' Factors of a Tourist Destination: The Role of Nationality - An Analytical Qualitative Research Approach. Current Issues in Tourism, 14(2): 121-143.

Robbins, S. ve Judge, T. (2013). Örgütsel Davranış. İstanbul: Nobel Yayın Dağıtım.

Sangpikul, A. (2008). Travel Motivations of Japanese Senior Tavellers to Thailand. International Journal of Tourism Research, 10(1): 81-94.

Snepenger, D., King, J., Marshall, E. ve Uysal, M. (2006). Modeling Iso-Ahola's Motivation Theory in the Tourism Context. Journal of Travel Research, 45(2): 140-149.

Şenol, F. (2010, Mart). Motivasyon Araçlarının Algılanmasında İş Güvencesinin Etkisi: Afyon Karahisar Otel işletmelerinde Bir araştırma. Yayınlanmış Doktora Tezi. Afyonkarahisar: Afyon Kocatepe Üniversitesi Sosyal Bilimler Enstitüsü.

Tarakçıŏlu, S., Sökmen, A. ve Boylu, Y. (2010). Motivasyon Araçlarının Değerlendirilmesi: Ankara'da Bir Araştırma. Işsletme Araştırmaları Dergisi, 2(1): 3-20.

Tutar, H., Yılmaz, K. ve Erdönmez, C. (2006). İşletme Becerileri Grup Çalışması. Ankara: Detay Yayıncılık.

Waterman, A. S. (2005). When Effort is Enjoyed: Two Studies of Intrinsic Motivation for Personally Salient Activities. Motivation and Emotion, 29(3): 165-188.

Wu, M.-Y. ve Pearce, P. L. (2014). Chinese Recreational Vehicle Users in Australia: A Netnographic Study. Tourism Management, 43: 22-35.

Yoon, Y. ve Uysal, M. (2005). An Examination of the Effects of Motivation and Satisfaction on Destination Loyalty: A Structural Model. Tourism Management, 26: 45-56.

You, X., O'leary, J., Morrison, A. ve Hong, G.-S. (2000). A Cross-Cultural Comparison Of Travel Push And Pull Factors: United Kingdom vs. Japan. International Journal Of Hospitality \& Tourism Administration, 1(2): 1- 26.

Yuan, S. ve Mcdonald, C. (1990). Motivational Determinants of International Pleasure Time. Journal of Travel Research, 29(1): 42-44.

Zhang, H. Q., Leung, V. ve Qu, H. (2007). A Refined Model of Factors Affecting Convention Participation Decision-making. Tourism Management, 28(4): 11231127. 